\title{
The Culture of Helping Indonesia in the Children's Story Book as Media for Character Education
}

\author{
Iis Suwartini ${ }^{1}$, Fitri Merawati ${ }^{2}$ \\ \{iis.suwartini@pbsi.uad.ac.id ${ }^{1}$,fitri.merawati@pbsi.uad.ac.id $\left.{ }^{2}\right\}$ \\ ${ }^{1,2}$ Pendidikan Bahasa dan Sastra Indonesia, Universitas Ahmad Dahlan, Yogyakarta, Indonesia \\ 55166
}

\begin{abstract}
Children's story is a literary work that contains cultural values. A culture of help is found in children's stories. The purpose of this study is for the form of help culture found in children's literature and its relation to character education. The research method uses descriptive research. Form of qualitative research. Data source in the form of document study. Document study data collection techniques. The results of the study include: (1) there are two forms of culture to help, namely help in the form of material and non-material, (2) children's stories can be applied in character education. The results of this study can be concluded that the culture of helping is reflected in children's stories and can be used as a medium for character education.
\end{abstract}

Keywords: Culture, help, character education

\section{Introduction}

A literary work as a result of human work can not be separated from the social conditions of the surrounding community [1]. Literature is often placed as a social portrait. Literature reflects the social conditions of society at a particular time. Literature provides an understanding of social, economic, cultural, religious and ideological situations that reflect local wisdom. Literature and culture are very interrelated. Literary works were born from the culture of the local community.

Culture develops and is standardized in the social traditions of a society. Culture belongs to the community which is used together as a guideline or frame of reference for the community members concerned in a variety of behaviors related to efforts to meet their daily needs [2].

Children's literature is one type of literature that promotes local wisdom. Children's literature is literature that talks about anything related to life's problems so that it can provide information and a better understanding of life itself to children [3]. Children's story is one of children's literary works that is being developed in Indonesia. One of the noble values of the nation's culture that is often raised in children's stories is help.

Helpful behavior as a part of prosocial behavior is seen as any action intended to benefit one or many people. Helpful behavior has been taught to individuals from an early age, from very simple things to things that can attract someone's empathy [4]. Please help is the result of encouragement in the soul in the form of loving and caring for others than yourself [5].

The helpful behavior contained in children's stories is closely related to character education. Character education is an effort to deal with the current multidimensional crisis problem. This is done by instilling values in education[6]. Character education is a system of 
instilling character values that includes components of knowledge, intelligence or will, and actions to implement these values [7].

Character education can also be understood as an effort designed systematically to understand the values of human behavior related to God, self, fellow human beings, the environment, and nationality manifested in thoughts, attitudes, feelings, words, and actions based on norms religion, law, etiquette, culture, and customs [8].

Characters can be formed from habituation. The earlier habituation is taught, the stronger the character grows in the child as explained by Hurlock [9]. Introducing children to literary works, especially children's stories, is an initial step to introduce cultural and educational values contained therein. This certainly greatly influences the formation of children's character. Over time the child will know the values of goodness and can distinguish the good from the right.

In this study using pragmatic studies. Wahyudi stated that the pragmatic approach is the approach of literary study that emphasizes his study of the role of readers in accepting, understanding, and living literary works [10]. Pragmatic analysis emphasizes the usefulness of the reader. This study discusses the forms of help in children's literature and their relation to character education.

\section{Method}

The method used in this research is descriptive method and qualitative research. Descriptive method to explain data or objects naturally, objectively, and factually. Qualitative research is research that produces data in the form of words aimed at understanding social phenomena including linguistic phenomena. The source of research data is children's stories. Document study data collection techniques. This research uses data triangulation, data triangulation (data triangulation) researchers use multiple data to collect the same data. Data triangulation techniques prioritize the effectiveness of the process and the desired results. Therefore, triangulation can be done by testing whether the process and the results of the method used are going well.

\section{Result and Discussion}

Helping behavior has become a culture in Indonesian society. Indonesian people are known to the world as good and helpful people. Please help, there are two forms, namely material and non-material. The forms of mutual help among humans contained in the majority of children's stories are non material.

That is because children are taught in advance to help in the form of non-material behavior. Children will be easier to give help abilities that he has such as skills and services. Children are not familiar with the material so it will be more difficult when teaching help in the form of material. This is the background of a number of folklore that teaches a lot of help in the form of non material material.

The behavior of Indonesian people who preserve a culture of help has become a national identity. To maintain and preserve a culture of help-helping since childhood students to cultivate help to their friends. One of the efforts they made was by raising the theme of helping for children's stories. The following are excerpts of children's stories that illustrate the form of please help in the form of non material love. 
"From up there, pigeons can see the ants they once hel him are at the hunter's feet. After making sure the hunter left and the situation was safe, the dove then approached the ant and thanked him. The ant responded by saying that it was his shoes he had done because the dove had also helped him first when he fell into the river."

The story above tells the story of friendship between pigeons and ants. When a pigeon is in danger of being shot by the hunter, the ants help it. Vice versa with pigeons. Pigeons have also helped ants that have almost drowned. The excerpt from the story contained mutual help behavior.

Children who have read the story will think that a culture of help needs to be done. Children will imagine if in trouble there will be people who help. The story above tells the ant that was helped by the dove from the hunter because the ant also helped the dove when it was in danger. Based on the story, the child will conclude the importance of a culture of help. In order for others to be willing to help their difficulties, they must also be willing to help others who need help. The following are excerpts of stories that also raise the theme of helping.

"Seeing the ant almost drowned, the elbow immediately looked for a dry leaf and he placed it on the surface of the river near the ant. The ant immediately climbed the leaf and the butterfly danced at the edge of the river. "Thank God, you survived ants, butterflies arrived on time to help you" said deer with those beautiful wings "said the ant. "Actually, we've met and know each other if you still remember ants, I'm a caterpillar that you've taunted. I just metamorphosed into a butterfly" answered the butterfly with a smile.

The story above tells the story of butterflies that are often teased by ants. One day the ant sank in the river. Butterflies are happy to help ants. A good butterfly helps without discrimination even with bad ants to it. Ants are aware of their mistakes. Now ants and butterflies are good friends and live helping each other.

The story is very inspiring because children are taught to provide help to anyone who is in need even if someone is mean to him. It is also not much different from Indonesian society which is found in the philosophy of life which reads "bad is rewarded with kindness." The behavior of helping does not expect a reply from humans but from God. So please help others without discriminating.

The story above also teaches children not to do bad things to others. it is possible that the people we treat are not good who will provide help. From the story above also teaches children to forgive the mistakes of others. When children can forgive the mistakes of others they also easily help others even though they have acted badly.

The following are excerpts from the help-help story full of sacrifice. Sometimes the people of Indonesia help others who are full of sacrifice who sacrifice their material, even their body and soul. That is what makes Indonesian people known as someone who likes to help.

"Do you want to eat another meal, the important thing is you want to eat? Say my friend, I'll find it for you," the squirrel offered to the cork fish. Really my dear friend, you want to find it for me? "Asked the cork fish." Right, my friend, I will find it for you, the important thing is that you want to eat so that you heal quickly and we can play together again, "the squirrel replied convincingly.

The story above tells the story of the sacrifice of the squirrel to its cork fish friend who is sick. Cork fish can be cured if you eat shark liver. It is not very easy for squirrels to get shark hearts. Squirrels have to sacrifice their bodies and lives to get shark hearts. Squirrels are willing to go into the sharks belly to get shark hearts.

In the story above, there is a sacrifice that is so great to help. In real life the story of sacrifice appears to the sar team volunteers who are willing to sacrifice their body and soul to 
save others. Help and assistance certainly need to be familiarized with early on because humans cannot live alone. Humans are social creatures who need help from others.

The helpful behavior contained in children's stories is closely related to Character education. Character education will be easier to teach since childhood. Children in general have not been able to distinguish what is good and what is bad. New children can mimic the behavior around them. Therefore, it is necessary to pay attention to various information obtained by the child. Children's stories are the first media for children to recognize cultural values, one of which is helping.

\section{Conclusion}

There are two types of help culture contained in children's stories, namely: (1) help in the form of material, and (2) help in the form of non material. The most helpful form of help found in a child's story is non material. A culture of help and assistance needs to be instilled in children since childhood so that the noble values of the nation's culture are not lost. The Indonesian people are known for their good personal and helpful people. Therefore, the culture of help that is contained in children's stories can be used as learning media as character education.

\section{Acknowledgements}

The author would like to thank LPPM Ahmad Dahlan University for funding our research.

\section{About the author}

1. Iis Suwartini (1987-), female, born in Kebumen, Jawa Tengah Province, Teacher Ahmad Dahlan University Email: iis.suwartini@pbsi.uad.ac.id

2. Fitri Merawati (1988-), fe male, bron in Bantul, Yogyakarta Province

Email: fitri.merawati@pbsi.uad.ac.id

\section{References}

[1] S. Tirto, "Karya-Karya Fiksi Ali Akbar Navis," Al-Qalam, vol. VIII, no. 1, pp. 59-64, 1989.

[2] Triyanto, "Pendidikan Seni Berbasis Budaya," Seni Imajin., vol. VIII, no. 1, pp. 3342, 2014.

[3] B. Nurgiantoro, "Sastra Anak: Persoalan Genre," Humaniora, vol. 16, no. 2, pp. 109122, 2004.

[4] I. D. G. U. dan I. M. R. Putra, "Hubungan Antara Perilaku Menolong Dengan Konsep Diri Pada Remaja Akhir Yang Menjadi Anggota Tim Bantuan Medis Janar Duta Fakultas Kedokteran Universitas Udayana," Psikol. Udayana, vol. 2, no. 2, pp. 198205, 2015.

[5] W. dan A. O. Qomaro Galuh, "Manifestasi Konsep Ta'awun Dalam Zaakwaarneming Prespektif Hukum Perikatan," Trunojoyo, vol. 1, no. 1, pp. 14-25, 2018.

[6] S. H. Hasan, "Pendidikan Sejarah Untuk Memperkuat Pendidikan Karakter," Paramita, vol. 22, no. 1, pp. 81-95, 2010.

[7] J. Indrastoeti, "Penanaman Nilai-Nilai Karakter Melalui Implementasi Pendidikan Karakter di Sekolah Dasar," in Prosiding Seminar Nasional Inovasi Pendidikan, 2003, 
pp. 284-292.

[8] I. Suyitno, "Pengembangan Pendidikan Karakter dan Budaya Bangsa Berwawasan Kearifan Lokal," J. Pendidik. Karakter, vol. 1, no. 1, pp. 1-13, 2012.

[9] V. Ardhyantama, "Pendidikan Karakter Melalui Cerita Rakyat pada Siswa Sekolah Dasar," Indones. J. Prim. Educ., vol. 1, no. 1, pp. 51-58, 2017.

[10] A. T. Gumono, “Analisis Film Denias dengan Pendekatan Pragmatik," J. Lang. Lit. Cult. Educ., vol. 13, no. 1, pp. 69-78, 2017. 